\title{
電流滴定法によるジチオカルバミン酸塩の迅速定量*
}

\author{
池出早苗，佐竹弘**
}

(1976 年 3 月 22 日受理)

\begin{abstract}
回転白金電極 $(1200 \mathrm{rpm})$ を指示電極 $(+0.7 \mathrm{~V})$ ，水銀一ヨウ化水銀 $(\mathrm{II})$ 電極を対極とする電流滴定 法によって，ジチオカルバミン酸塩を精度よく迅速定量する方法を検討した。

分析試料としてジメチルジチオカルバミン酸ナトリウム，ジメチルジチオカルパ、ン酸ジメチルフン モニウム，ジェチルジチオカルバミン酸ナトリウム， ジェチルジチオカルハミミン酸ジェチルアンモニウ ム及びピロリジンジチオカルバミン酸アンモニウムの 5 種類を用いた.

定量条件を吟味したところ，0.1 M アンモニア，0.1 M 䣷酸アンモニウム及び $0.1 \%$ リトン X100 からなる基礎液を用いることによって，上記ジチオカルバミン酸塩が硝酸銀標準液によって精度よ く滴定できることが明らかになった。
\end{abstract}

\section{1 繶言}

ジチオカルバミン酸䍀は多くの金属イオンと難溶性沈 殿1)を生成し，その沈殿がある種の有機溶媒に溶解する ことから，金属イオンの発色試薬，抽出試薬2) 及び金属 イオンの滴定剂3) として用いられている。 又，農莧4)51 及びゴムの加硫促進剂6)など広く利用されている.

水溶性のジチオカルバミン酸篮の分析方法としては中 和滴定法7)8)，ヨウ素滴定法910)，クロラ之ン'T法11), 塩 化ヨウ素法12)，シアン化臭素法13)14)及び酸分解法6)など がある. 又, 銀イオンを滴定削とする電学度滴定法 15 , 塩化水銀(II) を滴定剂と与る電流滴定法16) も報告されて いる.

著者らは回転白金電極 $(1200 \mathrm{rpm})$ を指示電極，水銀一 ヨウ化水銀(II) 電極を対極として, ジチオカルバミン 酸塩の電流-電位曲線を測定し, 限界酸化電流近傍で加 電压と滴定曲線の関係を調べ，最適の加電压下で酸化電 流を測定することによて，ジチオカルバミン酸䍀を硝 酸銀で電流滴定する方法究検部して, 精度よく定量でき る方法を確立したので報告する.

\section{2 試薬，装置及び実験方法}

\section{1 試 薬}

$0.01 \mathrm{M}$ ジチオカルバミン酸塩溶液 : ジメチルジチオ

*回転白金電極を指示電極とする電流滴定法に関する 分析化学的研究 (第 33 報). 前報は池田早苗, 本仲 純子：日化会誌, 1975, 1337

** 德島大学工学部応用化学科 : 德島県德島市南常三島 町 2-1
カルバミン酸ナトリウム (以下 DMDTC・Na と略す) は東京化成規格特級試薬を, ジメチルジチオカルバミン 酸ジメチルアンモニウム（以下 DMDTC. $\mathrm{NH}_{2}\left(\mathrm{CH}_{3}\right)_{2}$ と略す) は東京化成最純試薬を, ジェチルジチオカルバ ミン酸ナトリウム（以下 DEDTC・Na と略す） は和光 純薬特級試薬を, ジェチルジチオカルバミン酸ジェチル フンモニウム（以下 DEDTC. $\mathrm{NH}_{2}\left(\mathrm{C}_{2} \mathrm{H}_{5}\right)_{2}$ と略す）は 東京化成規格特級試薬を, ピロリジンジチオカルパミン 酸アンモニウム（以下 PDTC. $\mathrm{NH}_{4}$ と略す）以東京化成 規格特級試薬を使用した。これらをそれぞれ再蒸留水に 溶解して不溶物をろ過したものを原液とし, ヨウ素滴定 法10)により標定して用いた。これらを適当に希釈しアン モニアアルカリ性溶液として使用した。

$1 \mathrm{M}$ アンモニア水: 和光純薬の試薬特級アンモニア水 をうすめて用いた。

$1 \mathrm{M}$ 酶酸アンモニウム溶液 : 和光純薬試薬特級品を再 蒸留水に溶解して用いた。

トリトンX-100, トリトンX-405, ポリビニルピロリ ドン及びゼラチンは和光純薬の試薬を再蒸留水に溶解し 適当な浱度にして用いた。 その他の試薬はすべて特級品 を使用した。

\section{2 装置}

柳本直流ポーラログラフ P8-D 型，島津回転白金電極 装置 RE-50 型, 堀場 $\mathrm{pH}$ メーター F-5 型及び平沼産 業自動記録滴定装置 Rat 11 型を使用し，その他は既 報17)と同様なものを用いた。なお，ジメチルジチオカル バミン酸塩の 定量には酩酸アンモニウム-寒天塩橋を用 い, その他の試料の場合には硝酸カリウム一寒天塩橋を 使用した。

\section{3 実験方法}

滴定セルに試料溶液の一定量を正確に分取し, 最終濃 
度が $0.1 \mathrm{M}$ になるようアンモニア，0.1 M になるよう 酷酸アンモニウム，0.1\%になるようトリトンX-100 岩 それぞれ添加した後，水で全量を $50 \mathrm{ml}$ とする. 回転白 金電㥛 $(1200 \mathrm{rpm})$ を指示電極とし，水銀一ヨウ化水銀 (II) 電極に対して $+0.7 \mathrm{~V}$ に加電压し, 硝酸銀標準液 を滴加して常温で電流滴定を行う。滴定曲線はL字型と なり，滴定時間は 10 分以内である。なお，分析結果の 比較のための計算值はヨウ素滴足法:10)によ,て計算した ものである.

\section{3 笑験結果及び考祭}

\section{1 ジチオカルバミン酸塩の電流-電位曲線}

Usatenko ら ${ }^{3)}$ は回転白金電極と SCE 索朋い, $\mathrm{pH}$ 4.5〜7 で DEDTC.Naの電流一電任曲線を测定し, $(+$ $0.7 \sim+0.9 \mathrm{~V})$ て限界酸化電流が得られ，それが濃度に 比例することを明らかにし，銅合金中の銅の電流滴定に 忘用している。

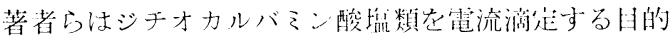
で，まず 2.3 と同様赫溶液組成のアンモニアアルカり性 の $0.0002 \mathrm{M} \mathrm{DEDTC} \cdot \mathrm{Na}$ 溶液について, 回転白金電極 と水銀-ヨウ化水銀 $(\mathrm{II})$ 䉓桠老用い, $(+0.3 \sim+1.1) \mathrm{V}$ の範囲で電流一電位曲線を測定し，Fig. 1 に示すような 曲線を得た。限界電流は $(+0.7 〜+0.9) \mathrm{V} て ゙$ 㴔められ, これが DEDTC・Naの濃度に比例することを確認した。 従って，検量線法でも定量できるが精度があまりよくな いので電流滴足法を尖施することにした。

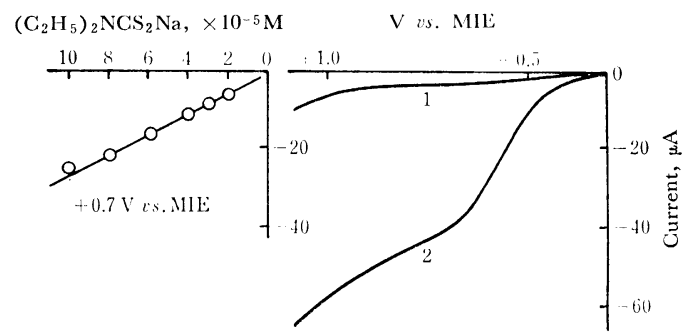

Fig. 1 Gurrent-voltage curve for sodium diethyldithiocarbamate

$50 \mathrm{ml}$ of $0.1 \mathrm{M} \mathrm{CH}_{3} \mathrm{COONH}_{4}, 0.1 \mathrm{M} \mathrm{NH}_{4} \mathrm{OH}, 0.1 \% \mathrm{Tri}-$ ton $\mathrm{X}-100 ; \quad 1:$ Without $\left(\mathrm{C}_{2} \mathrm{H}_{5}\right)_{2} \mathrm{NCS}_{2} \mathrm{Na} ; \quad 2:$ With $0.0002 \mathrm{M}\left(\mathrm{C}_{2} \mathrm{H}_{5}\right)_{2} \mathrm{NCS}_{2} \mathrm{Na} ; \quad$ Indicator electrode : Rotating platinum electrode $(1200 \mathrm{rpm}$ ) (Washing with $\mathrm{HNO}_{3}$ then $\left.\mathrm{NH}_{4} \mathrm{OH}\right) ; \quad$ Reference electrode : Mercurymercury(II) iodide electrode (MIE)

次に $0.002 \mathrm{M}$ DEDTC・Na 溶液を倣い電死值と 滴定曲線の 形状の関係を 調べた. Fig. 2 に示すように $(+0.8 \sim+1.1) \mathrm{V}$ では終点後の残余電流が大きくなる

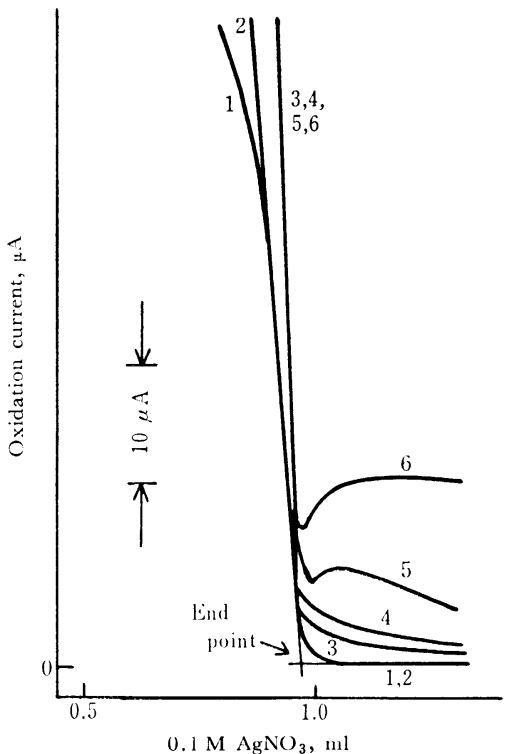

Fig. 2 Effect of applied potential on the titration curve for sodium diethyldithiocarbamate $50 \mathrm{ml}$ of $0.002 \mathrm{M}\left(\mathrm{C}_{2} \mathrm{H}_{5}\right)_{2} \mathrm{NCS}_{2} \mathrm{Na}, 0.1 \mathrm{M} \mathrm{CH}_{3} \mathrm{COONH}_{4}$, $0.1 \mathrm{M} \mathrm{NH}_{4} \mathrm{OH}, 0.1 \%$ Triton X-100; Applied voltage vs. MIE-1 $:+0.6 \mathrm{~V}, 2:+0.7 \mathrm{~V}, 3:+0.8 \mathrm{~V}, 4:$ $+0.9 \mathrm{~V}, 5:+1.0 \mathrm{~V}, 6:+1.1 \mathrm{~V}$

とともに電流值が安定せず終点の求め方が難しくなの た. $(+0.6 〜+0.7) \mathrm{V}$ では滴定曲線のこう配がやや小 さくなるが，終点後の直線性がよく，安定した曲線が得 られた。

以上のことより 水銀-ヨウ化水銀 (II) 電極沉 対して $+0.7 \mathrm{~V}$ に加電厓して電流淌定することにした。

\section{2 pH の影響}

ジチオカルバミン酸缊につき $0.002 \mathrm{M}$ ，トリトン X100 につき $0.1 \%$ 及び䣷酸アンモ二ウムにつき $0.1 \mathrm{M}$ の溶液 $50 \mathrm{ml}$ の $\mathrm{pH}$ を, 酸性侧は硫酸, アルカリ性侧 はアンモニア水で適当に調節 $(\mathrm{pH} \leqq 11.5)$ して滴定し， その影響を検討したところ, Table 1 に示すような $\mathrm{pH}$ で各試料の定星が可能であった。

Table 1 Suitable $\mathrm{pH}$ for the determination of dithiocarbamate

\begin{tabular}{ll}
\hline \multicolumn{1}{c}{ Sample } & $\mathrm{pH}$ \\
\hline$\left(\mathrm{CH}_{3}\right)_{2} \mathrm{NCS}_{2} \cdot \mathrm{Na}$ & $7.0 \leqq$ \\
$\left(\mathrm{CH}_{3}\right)_{2} \mathrm{NCS}_{2} \cdot \mathrm{NH}_{2}\left(\mathrm{CH}_{3}\right)_{2}$ & $7.0 \leqq$ \\
$\left(\mathrm{C}_{2} \mathrm{H}_{5}\right)_{2} \mathrm{NCS}_{2} \cdot \mathrm{Na}$ & $7.0 \leqq$ \\
$\left(\mathrm{C}_{2} \mathrm{H}_{5}\right)_{2} \mathrm{NCS}_{2} \cdot \mathrm{NH}_{2}\left(\mathrm{C}_{2} \mathrm{H}_{5}\right)_{2}$ & $8.0 \leqq$ \\
$\mathrm{C}_{4} \mathrm{H}_{8} \mathrm{NCS}_{2} \cdot \mathrm{NH}_{4}$ & $8.0 \leqq$ \\
\hline
\end{tabular}

Sample : $0.002 \mathrm{M} 50 \mathrm{ml}$ 
各試料ともに $\mathrm{pH} 8$ 以上では精度よく分析できるが， Table 1 に示す值以下の $\mathrm{pH}$ では負の䛊差を生じた. これはジチオカルバミン酸塩がアルカリ性側では安定で あるが，水素イオン濃度の増加とともに不安定になって 分解するためと考えられる.

従って，以後の実験では最終濃度が $0.1 \mathrm{M}$ になるよ うアンモニアを添加し， pH を9.5 程度にして滴定する ことにした。

\section{3 支持電解質（共存塩類）の影響}

$0.002 \mathrm{M} \mathrm{DEDTC} \cdot \mathrm{Na}$ 溶液 $50 \mathrm{ml}$ の電流滴走に财与 る共存壏類の影響を検討した. 酶酸ナトリウム，酶酸ア ンモ二ウム, 炭酸アンモ二ウム, 硝酸カリウム及び硝酸 ナトリウムをそれぞれ添加した場合の電流滴定曲線を示 吃と Fig. 3 のようになった。酢酸アンモニウム又は炭 酸アンモニウムを添加した場合には良好な滴定曲線を与 え，その他の場合には直線性が㤠くなった，又，其存熄 類を添加しない場合には負の䛊差を与え，低濃度の試料 では指示電流が著しく小さくなり，精度が悪くなる傾向 を示した、な括ジチルジチオカルバミン酸塩について も问様な検討を行ったところ，酶酸アンモニウムと炭酸

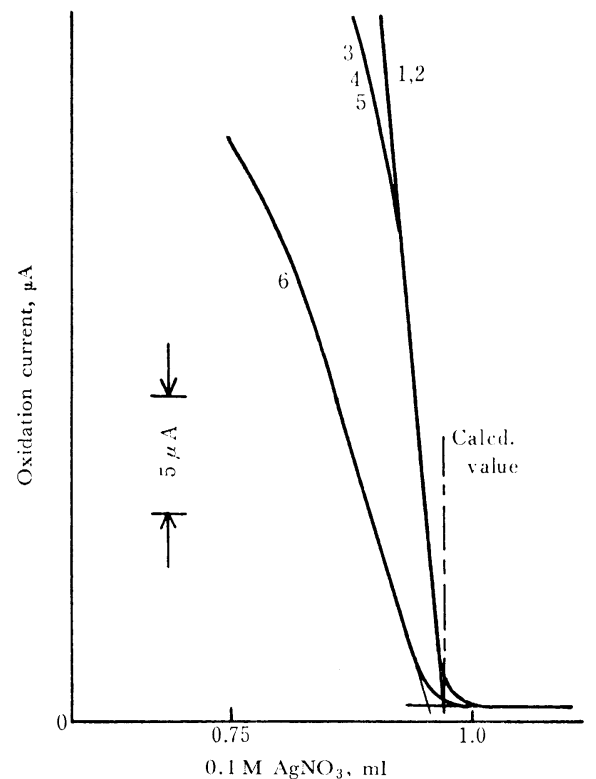

Fig. 3 Effect of supporting electrolyte on the titration curve for sodium diethyldithiocarbamate

$50 \mathrm{ml}$ of $0.002 \mathrm{M}\left(\mathrm{C}_{2} \mathrm{H}_{5}\right)_{2} \mathrm{NCS}_{2} \mathrm{Na}, 0.1 \mathrm{M}^{\mathrm{N}} \mathrm{NH}_{4} \mathrm{OH}$, $0.1 \%$ Triton $\mathrm{X}-100 ; 0.1 \mathrm{M}$ Supporting electrolyte$1: \mathrm{CH}_{3} \mathrm{COONH}_{4}, \quad 2:\left(\mathrm{NH}_{4}\right)_{2} \mathrm{CO}_{3}, \quad 3: \mathrm{NaNO}_{3}, 4:$ $\mathrm{KNO}_{3}, 5: \mathrm{CH}_{3} \mathrm{COONa}, 6:$ Absence
アンモニウム以外の場合には大きい正の誤差を与えた.

以上の結果を考慮して，支持電解質として酶酸アン モニウムを選び，適当な濃度範囲を検討したところ，

Table 2 に示すような範囲で精度のよい定量が可能であ ることが分かった.

Table 2 Suitable concentration ranges of ammonium acetate for the determination of dithiocarbamate

\begin{tabular}{lc}
\hline \multicolumn{1}{c}{ Sample } & $\mathrm{CH}_{3} \mathrm{COONH}_{4}(\mathrm{M})$ \\
\hline$\left(\mathrm{CH}_{3}\right)_{2} \mathrm{NCS}_{2} \cdot \mathrm{Na}$ & $0.05 \sim 0.2$ \\
$\left(\mathrm{CH}_{3}\right)_{2} \mathrm{NCS}_{2} \cdot \mathrm{NH}_{2}\left(\mathrm{CH}_{3}\right)_{2}$ & $0.02 \sim 0.3$ \\
$\left(\mathrm{C}_{2} \mathrm{H}_{5}\right)_{2} \mathrm{NCS}_{2} \cdot \mathrm{Na}$ & $0.02 \sim 0.3$ \\
$\left(\mathrm{C}_{2} \mathrm{H}_{5}\right)_{2} \mathrm{NCS}_{2} \cdot \mathrm{NH}_{2}\left(\mathrm{C}_{2} \mathrm{H}_{5}\right)_{2}$ & $0.02 \sim 0.3$ \\
$\mathrm{C}_{4} \mathrm{H}_{8} \mathrm{NCS}_{2} \cdot \mathrm{NH}_{4}$ & $0.05 \sim 0.3$ \\
\hline
\end{tabular}

Sample : $0.002 \mathrm{M} 50 \mathrm{ml}$

良,て, 以後の実験では支持電解質として, 最終濃度 で $0.1 \mathrm{M}$ になるよう酶酸アンモニウムを添加して各種 ジチオカルバミン酸塩の滴定を行うことにした.

\section{4 界面活性剤の添加効果}

$0.002 \mathrm{M}$ DEDTG· $\mathrm{Na}$ 溶液 $50 \mathrm{ml}$ に各種界面活性副 を添加して滴定したところ，Fig. 4 のような滴定曲線が

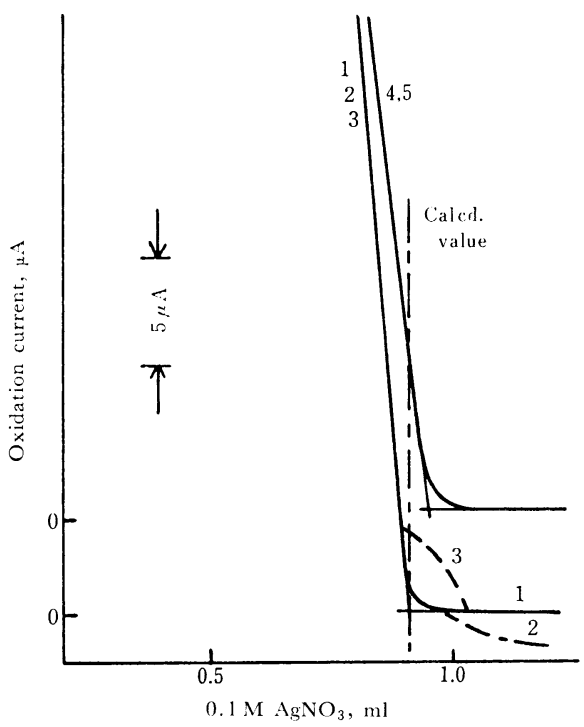

Fig. 4 Effect of surface active agent on the titration curve for sodium diethyldithiocarbamate $50 \mathrm{ml}$ of $0.002 \mathrm{M}\left(\mathrm{C}_{2} \mathrm{H}_{5}\right)_{2} \mathrm{NCS}_{2} \mathrm{Na}, 0.1 \mathrm{M} \mathrm{NH}_{4} \mathrm{OH}$, $0.1 \mathrm{M} \mathrm{CH}_{3} \mathrm{COONH}_{4} ; \quad$ Surface active agent $-1: 0.2$ $\%$ Triton X-100, 2: $0.2 \%$ Triton X-405, $3: 0.2 \%$ polyvinyl pyrrolidone, $4: 0.02 \%$ gelatin, $5:$ Absence 
得られた、すなわち界面活性剂を添加しない場合とゼラ チンを添加した場合には曲線 5 のようになり正の誤差を 与え, 又トリトン X-405 又はポリビニルピロリドンを 添加した場合には滴定曲線が乱れる傾向が䜑められた。

トリトン X-100を用いた場合には滴定曲線も良好で正 確な分析值を示すことが明らかになった。これは林18)ら の吸光分析に対する効果とも一致しているので, ジチオ カルバミン酸銀の沈殿がトリトン X-100によって可溶 化ないしコロイド溶液化するものと考えられる.

以上の結果からトリトンX-100 を使用することとし， その添加量の影響を検討したところ, Table 3 に示す濃 度範围が噃当であることが分かった。

Table 3 Suitable concentration ranges of Triton $\mathrm{X}-100$ for the determination of dithiocarbamate

\begin{tabular}{lc}
\hline \multicolumn{1}{c}{ Sample } & Triton X-100 $(\%)$ \\
\hline$\left(\mathrm{CH}_{3}\right)_{2} \mathrm{NCS}_{2} \cdot \mathrm{Na}$ & $0.02 \sim 0.4$ \\
$\left(\mathrm{CH}_{3}\right)_{2} \mathrm{NCS}_{2} \cdot \mathrm{NH}_{2}\left(\mathrm{CH}_{3}\right)_{2}$ & $0.05 \sim 1.0$ \\
$\left(\mathrm{C}_{2} \mathrm{H}_{5}\right)_{2} \mathrm{NCS}_{2} \cdot \mathrm{Na}$ & $0.05 \sim 1.0$ \\
$\left(\mathrm{C}_{2} \mathrm{H}_{5}\right)_{2} \mathrm{NCS}_{2} \cdot \mathrm{NH}_{2}\left(\mathrm{C}_{2} \mathrm{H}_{5}\right)_{2}$ & $0.05 \sim 1.0$ \\
$\mathrm{C}_{4} \mathrm{H}_{8} \mathrm{NCS}_{2} \cdot \mathrm{NH}_{4}$ & $0.02 \sim 1.0$ \\
\hline
\end{tabular}

Sample : $0.002 \mathrm{M} 50 \mathrm{ml}$

すなわち各試料の分析に際して，最終濃度で $0.1 \%$ に なるようトリトン X-100 を添加して滴定すればよい. な打低濃度の試料溶液の場合には $(0.01 〜 0.03) \%$ にな るようトリトン X-100 を添加するとよい結臬が得られ た。

\section{5 滴定温度の影響}

$0.002 \mathrm{M}$ の各試料溶液 $50 \mathrm{ml}$ 艺各温度で滴足したと ころ, ジチオルバミン酸塩の種類によ,てて定量可能な 温度範囲は異なるが，Table 4 に示す範用で正確な分析 ができることが分かいた。

すなわち，(15〜20) ${ }^{\circ} \mathrm{C}$ の常温で滴定すれば各試料と もに正確な結果が得られることが明らかになった。

Table 4 Suitable temperature ranges for the determination of dithiocarbamate

\begin{tabular}{lc}
\hline \multicolumn{1}{c}{ Sample } & Temperature $\left({ }^{\circ} \mathrm{C}\right)$ \\
\hline$\left(\mathrm{CH}_{3}\right)_{2} \mathrm{NCS}_{2} \cdot \mathrm{Na}$ & $15 \sim 60$ \\
$\left(\mathrm{CH}_{3}\right)_{2} \mathrm{NCS}_{2} \cdot \mathrm{NH}_{2}\left(\mathrm{CH}_{3}\right)_{2}$ & $12 \sim 22$ \\
$\left(\mathrm{C}_{2} \mathrm{H}_{5}\right)_{2} \mathrm{NCS}_{2} \cdot \mathrm{Na}$ & $5 \sim 40$ \\
$\left(\mathrm{C}_{2} \mathrm{H}_{5}\right)_{2} \mathrm{NCS}_{2} \cdot \mathrm{NH}_{2}\left(\mathrm{C}_{2} \mathrm{H}_{5}\right)_{2}$ & $10 \sim 50$ \\
$\mathrm{C}_{4} \mathrm{H}_{8} \mathrm{NCS}_{2} \cdot \mathrm{NH}_{4}$ & $10 \sim 50$ \\
\hline
\end{tabular}

Sample : $0.002 \mathrm{M} 50 \mathrm{ml}$

\section{6 定量限界と精度}

5 種類のジチオカルバミン睃嫶の主琶可能な濃度範旧 と正確度及び精度について众討したとこそ，Table 5 の 結果が得られた。

DMDTC.Na と DMDTG. $\mathrm{NH}_{2}\left(\mathrm{CH}_{3}\right)_{2}$ は $(0.002 \sim$ 0.004)M の場合に精度, 正確度ともによく, 比較的高 濃度の場合にのみ優れた分析結果を与えることが分か。 た。

DEDTC.Na， DEDTC. $\mathrm{NH}_{2}\left(\mathrm{C}_{2} \mathrm{H}_{5}\right)_{2}$ 及び PDTC. $\mathrm{NH}_{4}$ の場合には $(0.00002 \sim 0.004) \mathrm{M}$ の広範米にわた

Table 5 Determination of dithiocarbamate

\begin{tabular}{|c|c|c|c|c|c|c|}
\hline \multicolumn{3}{|c|}{ Concentration (M) } & \multicolumn{2}{|c|}{ Analytical value (mg) } & \multirow{2}{*}{$\begin{array}{l}\text { Relative error } \\
(\%)\end{array}$} & \multirow{2}{*}{$\begin{array}{c}\text { C. V. }{ }_{(\%)}^{\dagger \dagger} \\
\text { (\%) }\end{array}$} \\
\hline Sample & & $\mathrm{Ag}^{+}$ & Calcd.† & Found $+\dagger$ & & \\
\hline$\left(\mathrm{CH}_{3}\right)_{2} \mathrm{NCS}_{2} \cdot \mathrm{Na}$ & $\left\{\begin{array}{l}0.008 \\
0.004 \\
0.002 \\
0.0002\end{array}\right.$ & $\begin{array}{l}0.1 \\
0.1 \\
0.1 \\
0.01\end{array}$ & $\begin{array}{c}46.66 \\
23.33 \\
11.67 \\
1.167\end{array}$ & $\begin{array}{c}46.24 \\
23.34 \\
11.64 \\
1.322\end{array}$ & $\begin{array}{l}-0.9 \\
\pm 0.0 \\
-0.3 \\
+13\end{array}$ & $\begin{array}{l}0.1 \\
0.1 \\
0.4 \\
0.4\end{array}$ \\
\hline$\left(\mathrm{CH}_{3}\right)_{2} \mathrm{NCS}_{2} \cdot \mathrm{NH}_{2}\left(\mathrm{CII}_{3}\right)_{2}$ & $\left\{\begin{array}{l}0.004 \\
0.002 \\
0.001 \\
0.0002\end{array}\right.$ & $\begin{array}{l}0.1 \\
0.1 \\
0.1 \\
0.01\end{array}$ & $\begin{array}{c}30.56 \\
15.28 \\
7.610 \\
1.528\end{array}$ & $\begin{array}{l}30.51 \\
15.29 \\
7.774 \\
1.632\end{array}$ & $\begin{array}{l}-0.2 \\
+0.1 \\
+1.8 \\
+\quad 6.8\end{array}$ & $\begin{array}{l}0.1 \\
0.2 \\
0.3 \\
1.1\end{array}$ \\
\hline$\left(\mathrm{C}_{2} \mathrm{H}_{5}\right)_{2} \mathrm{NCS}_{2} \cdot \mathrm{Na}$ & $\left\{\begin{array}{l}0.004 \\
0.002 \\
0.0002 \\
0.00002 \\
0.000002\end{array}\right.$ & $\begin{array}{l}0.1 \\
0.1 \\
0.01 \\
0.001 \\
0.001\end{array}$ & $\begin{array}{c}43.83 \\
21.92 \\
2.192 \\
0.219 \\
0.022\end{array}$ & $\begin{array}{c}43.92 \\
21.98 \\
2.192 \\
0.214 \\
0.018\end{array}$ & $\begin{array}{l}+0.2 \\
+0.3 \\
\pm 0.0 \\
-2.3 \\
-18\end{array}$ & $\begin{array}{l}0.1 \\
0.2 \\
0.0 \\
0.4 \\
7.2\end{array}$ \\
\hline$\left(\mathrm{C}_{2} \mathrm{H}_{5}\right)_{2} \mathrm{NCS}_{2} \cdot \mathrm{NH}_{2}\left(\mathrm{C}_{2} \mathrm{H}_{5}\right)_{2}$ & $\left\{\begin{array}{l}0.004 \\
0.002 \\
0.0002 \\
0.00002+\dagger+\dagger \\
0.000002+\dagger+\dagger\end{array}\right.$ & $\begin{array}{l}0.1 \\
0.1 \\
0.01 \\
0.001 \\
0.001\end{array}$ & $\begin{array}{c}46.74 \\
22.78 \\
2.278 \\
0.228 \\
0.023\end{array}$ & $\begin{array}{l}46.83 \\
22.75 \\
2.270 \\
0.219 \\
0.021\end{array}$ & $\begin{array}{l}+0.2 \\
\pm 0.1 \\
=0.4 \\
=4.0 \\
-8.7\end{array}$ & $\begin{array}{l}0.1 \\
0.1 \\
0.1 \\
0.2 \\
1.2\end{array}$ \\
\hline $\mathrm{G}_{4} \mathrm{H}_{8} \mathrm{NCS}_{2} \cdot \mathrm{NH}_{4}$ & $\left\{\begin{array}{l}0.004 \\
0.002 \\
0.0004 \\
0.0002 \\
0.00002+\dagger+\dagger \\
0.000002+\dagger+\dagger\end{array}\right.$ & $\begin{array}{l}0.1 \\
0.1 \\
0.01 \\
0.01 \\
0.001 \\
0.001\end{array}$ & $\begin{array}{c}34.76 \\
15.58 \\
3.116 \\
1.558 \\
0.156 \\
0.016\end{array}$ & $\begin{array}{c}34.68 \\
15.57 \\
3.114 \\
1.552 \\
0.153 \\
0.015\end{array}$ & $\begin{array}{l}-0.2 \\
=0.1 \\
=0.1 \\
=0.4 \\
=1.9 \\
-6.3\end{array}$ & $\begin{array}{l}0.1 \\
0.2 \\
0.1 \\
0.2 \\
0.4 \\
0.7\end{array}$ \\
\hline
\end{tabular}

Total volume : $50 \mathrm{ml}$; † Iodometric method; †† Determination of (4 5) titrations; ††† Coefficient of variation; $\dagger+\dagger \dagger 0.02 \%$ Triton $\mathrm{X}-100$ solution 
って精度のよい分析值を与えることが明らかになった。 (0.002 0.004)M の場合には各種ジチオカル゙ミン 酸塩がいずれも $0.4 \%$ 以内の相则誤差と变動係数で定量 できた。

$$
4 \text { 維富 }
$$

回転白金電柇を指示電極 $(+0.7 \mathrm{~V})$, 水銀一ヨウ化水 銀(II) 電極を対極とする電流榈定法により, ジチオカ ルバミン酸熄を銀滴定する場合の定量条件を検討した.

ジチオカルバミン酸塩の電流滴定には $0.1 \mathrm{M}$ アンモ ニア，0.1 M 酶酸アンモニウム及び $0.1 \%$ トリトンX100 からなる基礎液が適当であり，(15〜20) ${ }^{\circ} \mathrm{C}$ の常温 で硝酸銀標準液で滴定することによって 5 種類のジチオ カルバミン酸塩が精度よく定量された。分析所要時間は 10 分以内であった。

この方法はトリトン X-100 の分敀作肺を利肜してジ チオカルバミン酸堛を进速かつ精度よく銀イオンで電流 滴定するところに特長があり，従来の有機溶媒を用い るヨウ素滴定法よりも操作隹簡単で，その他の方法と 比べても感度が高く分析可能な濃度範国も広いので, DMDTC.Na, DMDTC. $\mathrm{NH}_{2}\left(\mathrm{CH}_{3}\right)_{2}$, DEDTC.Na, DEDTC. $\mathrm{NH}_{2}\left(\mathrm{C}_{2} \mathrm{H}_{5}\right)_{2}$ 及び PDTC・ $\mathrm{NH}_{4}$ などの迅速分 析法として実用俩值があるものと考えられる.

$\left(\begin{array}{l}1976 \text { 年 } 2 \text { 月, 日本化学会九州・中国 } \\ \text { 四国支部合同大会におい一部発表 }\end{array}\right)$

\section{交献}

1) A. Hulanicki : Talanta, 9, 549 (1962).

2) 㴊 好良: “光電光度法 1 ”, 実験化学講座 15 上 巻, p. 126 (1957), (丸善).

3) J. T. Stock : “Amperometric Titration", p. 441 (1965), (Interscience Publishers Inc., New York).

4) 富田一郎：化学, 18, 805 (1963).

5) 黑野 等 : 化学工場, 1974, 1354.

6) J. H. Karchmer : "The Analytical Chemistry of Sulfur and its Compounds", p. 620 (1971), (Interscience Publishers Inc., New York).

7) M. L. Shankaranarayana, C. C. Patel : Anal. Chem., 33, 1398 (1961).

8) A. Hulanicki, L. Shishkova : Talanta, 12, 485 (1965).

9) A. L. Linch : Anal. Chem., 23, 293 (1951).

10) M. L. Shankaranarayana, C. G. Patel : Z. Anal. Chem., 179, 263 (1961).

11) G. G. R. Nair, T. Joseph, P. T. Joseph : ChemistAnalyst, 54, 111 (1965).

12) P. N. K. Nambisan, G. G. R. Nair : Anal. Chim. Acta, 54, 475 (1970).

13) P. G. Paul, P. K. Chauman, P. Parkash : Talanta, 21, 663 (1974).

14) P. C. Paul, N. C. Sharma, R. K. Chauhan, R. Parkash : Ind. J. Chem., 10, 227 (1972).
15) W. Scheele, G. Gensch : Kautschuk Gummi, 6, WT-147 (1953). (CA, 48, 3057).

16) H. Holzapfel, U. Stottmeister : Z. Anal. Chem., 234, 349 (1968).

17) 池田早苗：本誌，21，177 (1972).

18）林謙次郎，伊藤恭子：同上, 20, 1550 (1971).

$$
\hat{s}
$$

Rapid determination of dithiocarbamate by amperometric titration. (Studies on analytical methods by amperometric titrations using a rotating platinum electrode. XXXIII.) Sanae IKEDA and Hiromu Satake (Faculty of Engineering, Tokushima University, 2-1, Minamijosanjima-cho, Tokushima-shi, Tokushima)

An amperometric method for the rapid determination of five kinds of dithiocarbamate has been studied with use of a rotating platinum wire electrode (1200 $\mathrm{rpm})$ at the potential of $+0.7 \mathrm{~V}$ vs. mercury-mercury (II) iodide electrode.

It was found that water-soluble dithiocarbamate could be titrated at room temperature with silver nitrate standard solution by measuring the oxidation current of dithiocarbamate in the presence of Triton $\mathrm{X}-100$, ammonia and ammonium acetate. Ammonium acetate or ammonium carbonate was suitable for the supporting electrolyte.

Sodium diethyldithiocarbamate and diethylammonium diethyldithiocarbamate could be precisely determined at their concentrations from $0.00002 \mathrm{M}$ to $0.004 \mathrm{M}$. The precisest determination was testified in the concentration range of $(0.0002 \sim 0.004) \mathrm{M}$; both the relative error (r.e.) and coefficient of variation (c.v.) being about $0.2 \%$.

Ammonium pyrolidine- $N$-dithiocarbamate was determined with the r.e. and c.v. of about $0.2 \%$ at its concentrations from $0.0004 \mathrm{M}$ to $0.004 \mathrm{M}$.

Sodium dimethyldithiocarbamate and dimethylammonium dimethyldithiocarbamate were determined with the r.e. and c.v. of about $0.4 \%$ at their concentrations from $0.002 \mathrm{M}$ to $0.004 \mathrm{M}$.

The recommended procedure is as follows.

Measure $(10 \sim 20) \mathrm{mg}$ of dithiocarbamate into the titration cell. After the addition of ammonia, ammonium acetate and Triton $\mathrm{X}-100$ so that the final concentrations may be $0.1 \mathrm{M}, 0.1 \mathrm{M}$ and $0.1 \%$, respectively, add water to bring the volume to $50 \mathrm{ml}$.

Titrate the solution with $0.1 \mathrm{M}$ silver nitrate solution amperometrically.

The whole procedure requires only 10 minutes. (Received Mar. 22, 1976)

\section{Keywords}

Amperometric titration

Argentometry

Dithiocarbamate

Mercury-Mercury(II) iodide electrode

Rotating platinum electrode 